\title{
EFEKTIVITAS MODUL LARUTAN ELEKTROLIT DAN NONELEKTROLIT BERBASIS DISCOVERY LEARNING TERHADAP KETERAMPILAN BERPIKIR KRITIS DAN HASIL BELAJAR SISWA KELAS X MIPA SMAN 2 BUKITTINGGI
}

\author{
Dian Firda Lusi ${ }^{1)}$ Yerimadesi $^{(2)}$ Rahadian Zainul $^{(3)}$ \\ ${ }^{1)}$ Program Studi Pendidikan Kimia Jurusan Kimia FMIPA UNP \\ Dianlusi43@gmail.com
}

\begin{abstract}
Electrolyte and nonelectrolyte based discovery modules are available learning is valid and practical, but has not been tested its effectiveness. Therefore the study aims to reveal the effectiveness of electrolyte and nonelectrolyte solution modules on students' learning outcomes and critical thinking skills. The module effectiveness test is done through quasi experimental research with Pretest-Posttest Control Group Design design. Research population of all students of class X MIPA SMAN 2 Bukittinggi. The sample was taken by purposive random cluster sampling technique.. The research instrument used in the form of learning result test and critical thinking skill assessment sheet. Techniques of data analysis of learning outcomes by using SPSS 16 software and critical thinking skills with percentage techniques. Based on the result of the research, it is found that the experimental class $N$-gain (0.76) is higher than control class (0.67). The data analysis technique showed that the experimental and control classes were normally distributed and had homogeneous variance, so the ttest was performed. From the result of t-test analysis obtained (sig) $0.006<0.05$ which indicates that experiment class learning outcomes are significantly higher than control class. Based on the data analysis of students critical thinking skills, the average score of students' critical thinking skills is $87 \%$. The research findings show that the use of electrolyte and nonelectrolyte based discovery modules learning effective on student learning outcomes and critical thinking skills at SMAN 2 Bukittinggi
\end{abstract}

Keyword : Electrolyte and Nonelectrolyte Solutions, Discovery Learning-based, Modules, Learning Outcomes, Critical Thinking Skills.

\section{PENDAHULUAN}

Pendidikan memiliki peranan penting dalam kehidupan manusia. Melalui pendidikan manusia dapat mengembangkan potensi yang dimilikinya dan menambah pengetahuan baru. Manusia membutuhkan pendidikan yang bermutu karena melalui pendidikan bermutu akan lahir pribadi yang berkualitas. Tujuan nasional pendidikan dalam UU Nomor 20 Tahun 2003 (Depdiknas, 2003: 4) adalah mewujudkan suasana pembelajaran yang dapat mengembangkan potensi peserta didik agar menjadi manusia yang beriman dan bertaqwa kepada Tuhan yang Maha Esa, berakhlak mulia, sehat, berilmu, cakap, kreatif, mandiri. Salah satu upaya untuk mewujudkan tujuan pendidikan nasional tersebut, maka di sekolah dilaksanakan pembelajaran berbagai bidang studi, diantaranya adalah Kimia. Salah satu materi kimia yang dipelajari yaitu larutan elektrolit dan nonelektrolit.

Materi larutan elektrolit dan nonelektrolit dipelajari menggunakan pendekatan saintifik. Pendekatan saintifik menuntun siswa belajar secara ilmiah dan merupakan bentuk pembelajaran yang berpusat pada peserta didik. Ada beberapa model yang mendukung proses pembelajaran saintifik, salah satunya adalah menggunakan model discovery learning. Model discovery learning dapat diterapkan dengan menggunakan bahan ajar berupa modul.

Modul merupakan salah satu bahan ajar yang menunjang siswa belajar mandiri untuk menemukan sebuah konsep, sehingga meningkatkan kreativitas dan hasil belajar siswa. Namun, pembelajaran kimia di sekolah guru belum menggunakan bahan ajar berupa modul yang sesuai dengan kurikulum 2013, tetapi menggunakan media powerpoint. Media 
powerpoint belum sepenuhnya membuat siswa bisa menemukan konsep sendiri, sehingga siswa lebih cenderung untuk menghapal. Siswa belum sepenuhnya aktif dalam proses pembelajaran, yang menyebabkan rendahnya kemampuan berpikir kritis siswa selama proses pembelajaran. Penelitian yang dilakukan oleh Syamsul (2013) menghasilkan modul sistem koloid dapat memacu respon positif siswa dalam proses pembelajaran dan guru dapat mengolah pembelajaran dengan baik serta hasil belajar siswa dapat meningkat dengan menggunakan modul. Penelitian yang dilakukan oleh Yerimadesi (2016) menginformasikan bahwa modul kesetimbangan kimia berbasis pendekatan saintifik untuk kelas $X$ SMA/MA yang dihasilkan memiliki kriteria valid, praktis dan efektif. Oleh karena itu modul ini dapat digunakan untuk pembelajaran kimia sesungguhnya di SMA/MA kelas XI discovery dengan siswa yang menggunakan pengajaran langsung. Sejalan dengan itu, Galuh (2015) menyatakan bahwa penerapan model discovery learning meningkatkan aktivitas dan prestasi belajar siswa pada materi larutan penyangga.

Yerimadesi (2017) menginnformasikan bahwa penggunaan modul berbasis discovery learning efektif dalam meningkatkan hasil belajar siswa kelas XI MIA SMAN 7 Padang. Hasil belajar siswa yang menggunakan modul larutan penyangga berbasis discovery learning lebih tinggi secara signifikan daripada hasil belajar siswa yang menggunakan pembelajaran konvensional di kelas XI MIA SMAN 7 Padang. Pembelajaran menggunakan modul berbasis discovery learning dapat memacu keterampilan berpikir kritis peserta didik, dimana model discovery learning menuntut siswa untuk dapat menemukan konsep sendiri dan menyelesaikan masalah yang dihadapi secara ilmiah. Berpikir kritis merupakan kegiatan menganalisa gagasan kearah yang lebih spesifik, mengidentifikasi dan mengkaji sacara sempurna.

Fitri (2014) menyatakan bahwa terdapat perbedaan keterampilan berpikir kritis antara siswa yang diajar menggunakan model discovery learning dengan pendekatan saintifik dengan siswa yang diajar dengan menggunakan model cooperative learning dengan pendekatan saintifik. Pembelajaran dengan model discovery learning dengan pendekatan saintifik memberikan peningkatan hasil belajar dengan effect size sebesar 0,78 (tergolong sedang) pada materi larutan elektrolit dan non elektrolit. Sunaryo (2014) menyatakan bahwa peningkatan keterampilan berpikir kritis dan kreatif matematik siswa yang pada pembelajarannya menerapkan model pembelajaran berbasis masalah lebih baik dari peningkatan kemampuan berpikir kritis dan kreatif matematik siswa yang pada pembelajarannya menerapkan model pembelajaran langsung. Sikap siswa terhadap penerapan model pembelajaran berbasis masalah menunjukkan sikap positif. Assosiasi antara sikap siswa pada penerapan model pembelajaran berbasis masalah dan peningkatan kemampuan berpikir kritis dan kreatif matematik siswa menunjukkan assosiasi yang cukup kuat.

Esi Prayesa (2017) menyatakan bahwa modul elektrolit dan nonelektrolit berbasis discovery learning pada tingkat SMA memiliki kategori kevalidan dan kepraktisan yang sangat tinggi namun efektivitasnya terhadap hasil belajar siswa belum diuji. Berdasarkan latar belakang diatas, maka dilakukan penelitian dengan judul "Efektivitas Modul Larutan Elektrolit dan Nonelektrolit Berbasis Discovery Learning terhadap Keterampilan Berpikir Kritis dan Hasil Belajar Siswa Kelas $X$ MIPA SMA Negeri 2 Bukittinggi”.

\section{METODE PENELITIAN}

Penelitian ini merupakan lanjutan penelitian R\&D pada tahap develop yaitu efektivitas. Pada penelitian sebelumnya telah diuji validitas dan praktikalitas, oleh karena itu pada penelitian ini dilanjutkan dengan uji efektivitas melalui penelitian eksperimen semu. Desain penelitian adalah PretestPosttest Control Grup Design. Pada desain penelitian ini terdapat dua kelas yang masingmasing dipilih secara random (R), yaitu kelas eksperimen (X MIPA 5) dan kelas kontrol (X MIPA 2). Kelas eksperimen dan kelas kontrol diberi pretest dan posttest. Kelas eksperimen dalam pembelajaran menggunakan modul berbasis Discovery Learning, sedangkan kelas kontrol menggunakan buku atau bahan ajar yang disediakan sekolah.

Tabel 1. Desain Penelitian Pretest-Posttest Control Grup Design

\begin{tabular}{cccc}
\hline \multirow{2}{*}{ Sampel } & Pretes & Perlakua & Postes \\
& $t$ & $\mathrm{n}$ & $t$ \\
\hline
\end{tabular}




\begin{tabular}{cccc}
\hline $\begin{array}{c}\text { Eksperime } \\
\mathrm{n}\end{array}$ & $\mathrm{O}_{1}$ & $\mathrm{X}_{1}$ & $\mathrm{O}_{2}$ \\
\hline Kontrol & $\mathrm{O}_{1}$ & $\mathrm{X}_{3}$ & $\mathrm{O}_{2}$ \\
\hline
\end{tabular}

Populasi pada penelitian ini adalah siswa kelas X MIPA semester genap tahun ajaran 2017/2018 di SMA Negeri 2 Bukittinggi. Pengambilan sampel dilakukan dengan menggunakan teknik purposive random cluster sampling. Instrumen penelitian yang digunakan adalah tes hasil belajar (pretest dan posttest) dan lembar penilaian keterampilan berpikir kritis. Tes yang digunakan sesuai dengan materi yang diberikan selama perlakuan berlangsung.

\section{A. Analisis Data Hasil Belajar (N-gain)}

Hasil pretest dan posttest selanjutnya diolah dan dianalisis untuk mengetahui adanya peningkatan hasil belajar. Data tes hasil belajar siswa sebelum dan sesudah perlakuan dianalisis dengan cara membandingkan nilai tes awal dan nilai tes akhir pada kelompok eksperimen dan kelompok kontrol. Peningkatan yang terjadi sebelum dan sesudah pembelajaran diperhitungkan dengan rumus $\mathrm{N}$-gain (normalized-gain). Gain adalah selisih antara nilai pretest dan posttest. Gain menunjukkan peningkatan pemahaman atau penguasaan konsep siswa setelah pembelajaran. Adapun rumus N-gain yaitu :

$$
N-\text { gain }=\frac{\text { skor posttest }(\%)-\text { skor pretest }(\%)}{\text { skor } \text { max }- \text { skor pretest }(\%)}
$$

Dengan rumus gain ternormolisasi (N-gain) menurut Hake (1999), yaitu :

$$
N-\text { gain }=\frac{\% \text { skor } \text { posttest }-\% \text { skor pretest }}{100-\% \text { skor pretest }}
$$

Hasil perhitungan gain ternormalisasi (N-gain) kemudian diinterpretasikan dengan menggunakan klasifikasi Hake (1999) seperti pada Tabel 2.

Tabel 2. Klasifikasi gain ternormalisasi

\begin{tabular}{cc}
\hline Besarnya Gain $(\mathbf{g})$ & Klasifikasi \\
\hline $\mathrm{g} \leq 0,70$ & Tinggi \\
\hline $0,30 \leq \mathrm{g} \leq 0,70$ & Sedang \\
\hline $\mathrm{g}<0,30$ & Rendah \\
\hline
\end{tabular}

(Hake, 1999)

\section{B. Teknik Analisis Data}

Sebelum menguji hipotesis, terlebih dahulu dilakukan uji normalitas dan uji homogenitas.

\section{Uji Normalitas}

Uji normalitas bertujuan untuk melihat apakah sampel terdistribusi normal atau tidak. Untuk menguji normalitas digunakan uji
Shapiro-Wilk. Dari pengolahan data diperoleh sampel mempunyai nilai signifikan (sig) > dari $\alpha($ taraf nyata $)=0.05$, maka $\mathrm{H}_{0}$ diterima. Hal ini menandakan kelas sampel terdistribusi normal.

2. Uji Homogenitas

Uji homogenitas bertujuan untuk mengetahui apakah data pada kedua kelas sampel sudah mempunyai varians yang homogen atau tidak. Kriteria pengambilan $\mathrm{H}_{0}$ berdasarkan pada tabel test of homogenity of variance. Jika taraf signifikan $>\alpha(0,05)$ maka data terdistribusi homogen.

3. Uji Hipotesis

Uji hipotesis bertujuan untuk menentukan apakah hipotesis penelitian dapat diterima atau ditolak. Hipotesis tersebut ditulis dalam bentuk hipotesis statistik dengan uji satu pihak yaitu.
Ho : $\mu_{1}=\mu_{2}$
$\mathrm{H}_{1}: \mu_{1}>\mu_{2}$

Keterangan :

$\mu_{1}$ : Skor rata- rata kelas eksperimen

\section{$\mu_{2}$ : Skor rata- rata kelas kontrol}

Kriteria penerimaan $\mathrm{H}_{0}$ adalah terima $\mathrm{H}_{0}$ jika nilai signifikansi $>0.05$ dan tolak $\mathrm{H}_{0}$ jika sebaliknya. Berdasarkan data didapatkan nilai pada kedua sampel lebih kecil dari $\alpha=0.05$, sehingga dapat dinyatakan bahwa penggunaan modul larutan elektrolit dan nonelektrolit berbasis discovery learning efektif meningkatkan kompetensi kognitif lebih tinggi secara signifikan dibandingkan dengan sampel yang tidak menggunakan modul berbasis discovery learning. Hal ini menandakan hipotesis penelitian diterima.

\section{Teknik Analisis Keterampilan Berpikir Kritis}

Penilaian terhadap indikator berpikir kritis dilakukan dengan menganalisis nilai dari analisis jawaban modul siswa pada lembar kegiatan (LK) siswa dan lembar kerja siswa (LKS), penilaian didasarkan pada indikator dan rubrik penilaian keterampilan berpikir kritis, kemudian menjadikan dalam bentuk persen. Persentase dicari dengan menggunakan rumus :

$$
\% \text { Nilai }=\frac{\text { Nilai yang diberi }}{\text { Nilai Total }} \times 100 \%
$$

Persentase perolehan analisis jawaban siswa selanjutnya diketegorikan menjadi 5 berdasarkan pengkategorian keterampilan berpikir kritis yang diadaptasi dari riduwan (2015) yaitu sebagai berikut ini: 
Tabel 3. Kategori Persentase Keterampilan Berpikir Kritis

\begin{tabular}{ccc}
\hline No & $\begin{array}{c}\text { Persentase } \\
(\boldsymbol{\%})\end{array}$ & $\begin{array}{c}\text { Kategori } \\
\text { Efektivitas }\end{array}$ \\
\hline 1 & $81-100$ & Sangat Tinggi \\
\hline 2 & $61-80$ & Tinggi \\
\hline 3 & $41-60$ & Sedang \\
\hline 4 & $21-40$ & Rendah \\
\hline 5 & $0-20$ & Sangat Rendah \\
\hline (Riduwan, 2015)
\end{tabular}

\section{HASIL DAN PEMBAHASAN}

\section{A. Deskripsi Data}

Berdasarkan hasil penelitian diperoleh data hasil belajar siswa kelas sampel. Hasil belajar siswa diperoleh dari pretest dan posttest. Soal yang diberikan berupa soal pilihan ganda sebanyak 25 butir soal. Siswa yang menjawab benar diberi skor 1 dengan nilai 4 dan siswa yang menjawab salah diberi skor 0 dengan nilai 0 . Berdasarkan hasil perhitungan nilai pretest dan posttest pada kelas eksperimen dan kelas kontrol diperoleh nilai selisih dari kedua test yang telah diketegorikan menggunakan formulasi $\mathrm{N}$-gain yang terlihat pada Tabel 4.

Tabel 4. Deskripsi N-gain Kelas Sampel

\begin{tabular}{cccccc}
\hline \multirow{2}{*}{ Kelas } & \multirow{2}{*}{$\mathbf{N}$} & \multicolumn{3}{c}{ Rata-rata } & \multirow{2}{*}{ Kategori } \\
\cline { 3 - 5 } & & Pretest & Postest & N-gain & \\
\hline Eksperimen & 36 & 30.55 & 83.22 & 0.76 & Tinggi \\
\hline Kontrol & 36 & 29.77 & 78.11 & 0.67 & Sedang \\
\hline
\end{tabular}

Dari Tabel 4 terlihat bahwa siswa kelas eksperimen memperoleh nilai rata-rata $\mathrm{N}$-gain yaitu 0.76 dengan kategori tinggi. Pada siswa kelas kontrol nilai rata-rata $\mathrm{N}$-gain yaitu 0.67 dengan kategori sedang. Berdasarkan nilai Ngain, maka dapat dilakukan uji statistik untuk memperoleh normalitas, homogenitas dan uji hipotesis.

\section{Uji Normalitas}

Uji normalitas yang digunakan adalah uji Shapiro-Wilk. Hipotesis statistik untuk uji normalitas adalah:

$\mathrm{H}_{0}$ : data berdistribusi normal

$\mathrm{H}_{1}$ : data tidak berdistribusi normal

Kriteria pengambilan keputusan didasarkan pada taraf signifikan 0,05 dan data terdistribusi normal jika nilai signifikan (sig) $>\alpha(0,05)$ dan tolak $\mathrm{H}_{0}$ jika sebaliknya.
Tabel 5. Hasil Uji Normalitas N-gain Kelas Sampel

\begin{tabular}{ccccc}
\hline \multirow{2}{*}{ Kelas } & \multicolumn{3}{c}{ Shapiro-Wilk } & \multirow{2}{*}{ Kesimpulan } \\
\cline { 2 - 4 } Eksperimen & 0,977 & 36 & 0,65 & $\begin{array}{c}\text { Terdistribusi } \\
\text { Normal }\end{array}$ \\
\hline Kontrol & 0,953 & 36 & 0,13 & $\begin{array}{c}\text { Terdistribusi } \\
\text { Normal }\end{array}$ \\
\hline
\end{tabular}

Dari pengolahan data diperoleh sampel mempunyai nilai signifikan ( $\mathrm{sig}$ ) $>$ dari $\alpha$ (taraf nyata) $=0.05$, maka $\mathrm{H}_{0}$ diterima. Hal ini menandakan kelas sampel terdistribusi normal. 2. Uji Homogenitas

Uji homogenitas bertujuan untuk mengetahui apakah data pada kedua kelas sampel sudah mempunyai varians yang homogen atau tidak. Kriteria pengambilan $\mathrm{H}_{0}$ berdasarkan pada tabel test of homogeneity of variance. Jika taraf signifikan $>\alpha(0,05)$ maka data terdistribusi homogen.

Tabel 6. Hasil Uji homogenitas N-gain Kelas Sampel

\begin{tabular}{cccccc}
\hline Kelas & Statistik & df1 & df2 & Sig & Keputusan \\
\hline $\begin{array}{c}\text { Eksperimen } \\
\text { Kontrol }\end{array}$ & 2,455 & 1 & 70 & 0,12 & Homogen \\
\hline
\end{tabular}

3. Uji Hipotesis

Kriteria penerimaan $\mathrm{H}_{0}$ adalah terima $\mathrm{H}_{0}$ jika nilai signifikansi $>0.05$ dan tolak $\mathrm{H}_{0}$ jika sebaliknya.

Tabel 7. Hasil Uji Hipotesis N-gain Kelas Sampel

\begin{tabular}{cccc}
\hline Kelas & $\boldsymbol{\alpha}$ & Sig & Keputusan \\
\cline { 1 - 3 } Eksperimen & 0.05 & 0.006 & $\begin{array}{c}\text { Tolak H0 } \\
\text { Terima H1 }\end{array}$ \\
\cline { 1 - 2 } Kontrol & Didapatkan nilai pada kedua sampel lebih
\end{tabular}

kecil dari $\alpha=0.05$, sehingga dapat dinyatakan bahwa penggunaan modul larutan elektrolit dan nonelektrolit berbasis discovery learning efektif meningkatkan kompetensi kognitif lebih tinggi secara signifikan dibandingkan dengan sampel yang tidak menggunakan modul berbasis discovery learning. Hal ini menandakan hipotesis penelitian diterima. 
Tabel 8. Rata-rara Lembar Kegiatan dan Lembar Kerja Siswa

\begin{tabular}{cccc}
\hline $\begin{array}{c}\text { Pert } \\
\text { ke }\end{array}$ & LK & LKS & $\begin{array}{c}\text { Nilai Akhir } \\
\text { (NA) }\end{array}$ \\
\hline 1 & 93 & 92 & 92 \\
\hline 2 & 83 & 91 & 86 \\
\hline 3 & 91 & 99 & 94.2 \\
\hline
\end{tabular}

Berdasarkan Tabel 8 terlihat bahwa rata-rata lembar kegiatan (LK) siswa disetiap pertemuan dengan lembar kerja siswa (LKS) tidak mengalami perbedaan yang singnifikan. Lembar kegiatan (LK) siswa dinilai berdasarkan tahapan pada model pembelajaran discovery learning sedangkan lembar kerja siswa (LKS) dinilai berdasarkan soal evaluasi yang diberikan diakhir pertemuan pembelajaran. Berdasarkan KKM yang ada di SMAN 2 Bukittinggi yaitu 75, maka dapat dilihat bahwa nilai keterampilan berpikir kritis siswa berada diatas KKM. Jika dilihat dari persentase nilai akhir lembar kegiatan (LK) siswa $(60 \%)$ dan lembar kerja siswa (LKS) (40\%), maka dapat disimpulkan bahwa keterampilan berpikir kritis siswa berada diatas KKM. Hal ini membuktikan bahwa penggunaan modul larutan elektrolit dan nonelektrolit berbasis discovery learning pada kelas eksperimen meningkatkan keterampilan berpikir kritis siswa.

\section{B. Pembahasan}

\section{Analisis Keterampilan Berpikir Kritis}

Berdasarkan Tabel 13 diperoleh persentase rata-rata keterampilan berpikir kritis siswa $87 \%$ dengan kategori sangat tinggi. Penilaian keterampilan berpikir kritis siswa berdasarkan indikator keterampilan berpikir kritis yang sesuai dengan model pembelajaran discovery learning. Indikator keterampilan berpikir kritis siswa yang digunakan sebanyak 11 indikator yaitu : 1) merumuskan masalah, 2) merumuskan hipotesis, 3) mencatat hasil pengamatan, 4) mendefenisikan istilah dan mempertimbangkan suatu defenisi, 5) melaporkan hasil percobaan dengan benar, 6) memberikan penjelasan sederhana, 7) membuat defenisi, 8) menuliskan argumen, 9) membuktikan hipotesis, 10) memberikan penjelasan lanjutan, 11) menuliskan kesimpulan.

Berdasarkan Tabel 13 terlihat bahwa pertemuan kedua terjadi penurunan nilai dibandingkan pertemuan pertama dan ketiga pada indikator merumuskan masalah (65\%), merumuskan hipotesis (68\%), mendefenisikan istilah dan mempertimbangkan suatu defenisi (92\%), membuktikan hipotesis (64\%), dan memberi penjelasan lanjutan (64\%). Dimana materi yang dipelajari pada pertemuan kedua yaitu penyebab kemampuan larutan elektrolit menghantarkan listrik. Pada materi tersebut siswa diminta untuk dapat menganalisis penyebab larutan elektrolit dapat menghantarkan listrik. Siswa diminta untuk dapat membuat reaksi ionisasi dari larutan elektrolit, dalam hal ini siswa masih mengalami kesulitan dalam memahami penguraian reaksi ionisasi.

Berdasarkan Tabel 13 diperoleh bahwa penggunaan modul berbasis discovery leraning dalam proses pembelajaran meningkatkan keterampilan berpikir kritis siswa. Hal ini sesuai dengan hasil penelitian kinasih (2015) bahwa penerapan model discovery learning berpengaruh signifikan dalam meningkatkan keterampilan berpikir kritis siswa pada materi sistem pertahanan tubuh. hal senada dikemukanan oleh Novayani, dkk (2015) dengan hasil penelitian bahwa penerapan model discovery learning berpengaruh dalam meningkatkan keterampilan berpikir kritis siswa pada materi pencemaran linkungan. Peningkatan keterampilan berpikir kritis siswa terjadi karena dalam tahapan model pembelajaran discovery learning mendorong siswa untuk aktif dalam proses pembelajaran, sehingga dapat mendorong siswa untuk berpikir dan menggunakan kemampuannya untuk menemukan hasil akhir berdasarkan pertanyaan-pertanyaan yang terdapat paka LK dan LKS. Keterampilan berpikir kritis merupakan suatu proses intelektual yang aktif dan penuh dengan keterampilan dalam membuat pengertian atau konsep, mengaplikasikan, menganalisis, mengenal permasalahan dan pemecahannya, menyimpulkan dan mengevaluasi setiap informasi yang didapat dari hasil pengamatan, pengalaman, akal sehat pemikiran dan komunikasi (Ellizar dan Djusmaini Djamas. 2012).

Modul yang digunakan disusun berdasarkan tahapan-tahapan berdasarkan model pembelajaran discovery learning. Adapun tahapan pada di discovery learning yang menimbulkan keterampilan berpikir kritis pada peserta didik adalah dengan 
memberikan rangsangan, dimana siswa akan menimbulkan pertanyaan dari rangsangan yang diberikan, rangsangan tersebut berupa materi yang akan dipelajari dan kaitannya dengan materi sebelumnya. Berdasarkan pertanyaan yang ditimbulkan, maka siswa akan mencari dan mengumpulkan data mengenai pertanyaan tersebut, sehingga siswa dapat memecahkan suatu permasalahan. Permasalahan yang telah dipecahkan akan membuat siswa memperoleh konsep baru. Konsep yang telah diperoleh dianalisis dan dibuktikan dengan data yang telah diperoleh. Pembuktian konsep akan menimbulkan kesimpulan dari konsep tersebut. Keterampilan berpikir kritis pada kelas sampel yang menggunakan modul discovery learning mengalami peningkatan, hal ini terlihat pada jawaban siswa yang terdapat pada lembar kegiatan dan jawaban lembar kerja siswa. Penilaian keterampilan berpikir kritis sesuai dengan indikator yang telah ditentukan dan pemberian skor dilakukan berdasarkan rubrik penskoran keterampilan berpikir kritis.

\section{Analisis Hasil Belajar}

Keefektifan modul discovery learning terhadap hasil belajar dapat diperoleh dari beberapa data yaitu nilai $\mathrm{N}$-gain, lembar kegiatan siswa dan lembar kerja siswa. Pada proses pembelajaran larutan elektrolit dan nonelektrolit di kelas eksperimen dan kelas kontrol sama-sama menggunakan model pembelajaran discovery learning. Model discovery learning adalah model pembelajaran untuk mengembangkan cara belajar siswa aktif dengan menemukan sendiri, menyelidiki sendiri, maka hasil yang diperoleh akan setia dan tahan lama dalam ingatan, tidak akan mudah dilupakan siswa (Hosnan, 2014:280). Hal yang membedakan pada penelitian ini adalah pada kelas eksperimen menggunakan modul larutan elektrolit dan nonelektrolit berbasis discovery learning, sedangkan pada kelas kontrol menggunakan buku yang tersedia di sekolah. Tahapan proses pembelajaran menggunakan model discovery learning dimulai dari tahap, 1) stimulation (pemberian rangsangan), 2) problem statement (rumusan masalah), 3) data collection (pengumpulan data), 4) data processing (pengolahan data), 5) verification (pembuktian), 6) generalitation (kesimpulan).

Berdasarkan Tabel 15 diperoleh rata-rata nilai $\mathrm{N}$-gain kelas eksperimen 0,76 dan kelas kontrol 0,67. Berdasarkan nilai $\mathrm{N}$-gain dari kedua kelas sampel terlihat bahwa nilai ratarata $\mathrm{N}$-gain kelas eksperimen lebih tinggi dibanding dibanding kelas kontrol yang menandakan bahwa selisih pretest dan posttest kelas eksperimen lebih tinggi dibandingkan dengan kelas kontrol.

Berdasarkan Tabel 16 dan 17 mengenai uji normalitas dan homogenitas kedua kelas sampel, diperoleh bahwa kedua kelas sampel terdistribusi normal dan memiliki varians yang homogen, sehingga pengujian hipotesis dilakukan dengan independent t-test. Berdasarkan Tabel 18 hasil uji-t untuk data Ngain kelas eskperimen dan kelas kontrol pada taraf signifikansi 0,05 , diperoleh nilai sig (2 tailed) 0,006 $<0,05$ dengan keputusan terdapat perbedaan pretest dan posttest, yang menandakan bahwa $\mathrm{H}_{1}$ diterima. Hasil belajar kognitif kelas yang menggunakan modul larutan elektrolit dan nonelektrolit berbasis discovery learning lebih tinggi secara signifikan dibanding kelas yang tidak menggunakan modul, yang berarti bahwa penggunaan modul larutan elektrolit dan nonelektrolit berbasis discovery learning efektif terhadap hasil belajar siswa. Hal ini sesuai juga dengan hasil penelitian Yerimadesi, dkk (2017) yang menyatakan bahwa, penggunaan modul larutan penyangga berbasis discovery learning efektif dalam meningkatkan hasil belajar siswa kelas XI MIA di SMAN 7 Padang. Hasil belajar siswa yang menggunakan modul berbasis discovery learning lebih tinggi secara signifikan dari pada hasil belajar siswa yang menggunakan pembelajaran konvensional di kelas XI MIA SMAN 7 Padang.

Berdasarkan data penelitian yang diperoleh menunjukkan bahwa hasil belajar kelas yang menggunakan modul larutan elektrolit dan nonelektrolit berbasis discovery learning lebih tinggi secara signifikan dibanding kelas yang tidak menggunakan modul dipengaruhi oleh beberapa faktor yaitu : 1) pembelajaran dengan menggunakan modul. Modul merupakan suatu unit yang lengkap yang berdiri sendiri dan terdiri atas suatu rangkaian kegiatan belajar yang disusun untuk membantu siswa mencapai sejumlah tujuan yang dirumuskan secara khusus dan jelas (Nasution.2011:205). Modul merupakan bahan ajar cetak yang memiliki komponen terlengkap dibandingkan bahan ajar lainnya, seperti LKS, dan handout. Modul memuat semua komponen penting dari bahan ajar, 
yaitu: judul, petunjuk belajar, KD, informasi pendukung, latihan, tugas/langkah kerja dan penilaian. Selain itu modul juga dilengkapi dengan kunci jawaban lembar kegiatan, kunci lembar kerja dan kunci lembar evaluasi, sehingga dengan modul siswa dapat mengukur kemampuannya sendiri dan dapat belajar sesuai kecepatan belajarnya masing-masing. Berdasarkan hasil penelitian Syamsul (2013) menyatakan bahwa penggunaan modul memacu respon positif siswa dalam proses pembelajaran dan guru dapat mengolah pembelajaran dengan baik sehingga hasil belajar siswa meningkat. Hal yang senada dikemukakan pada hasil penelitian yang dilakukan oleh Suryani D I, dkk (2014) yang menyatakan bahwa modul reaksi reduksi oksidasi yang dihasilkan dapat meningkatkan hasil belajar siswa dan keaktifan siswa dalam proses pembelajaran pada materi reaksi reduksi oksidasi

Berdasarkan karakteristik bahan ajar yang digunakan, maka modul merupakan bahan ajar yang paling sesuai dengan karakteristik model discovery learning, yaitu sama-sama digunakan untuk menuntun siswa belajar mandiri. 2) penggunaan modul dengan model pembelajaran discovery learning. Model discovery learning adalah model pembelajaran untuk mengembangkan cara belajar siswa aktif dengan menemukan sendiri, menyelidiki sendiri, maka hasil yang diperoleh akan setia dan tahan lama dalam ingatan, tidak akan mudah dilupakan siswa (Hosnan, 2014:280). Modul berbasis discovery learning disusun berdasarkan urutan penyusunan modul yaitu cover, kompetensi inti, kompetensi dasar, indikator, tujuan pembelajaran, peta konsep, petunjuk penggunaan modul untuk guru dan siswa, lembar kegiatan (LK) siswa, lembar kerja siswa (LKS), soal evaluasi, kunci soal evaluasi, kunci lembar kegiatan, kunci lembar kegiatan siswa, daftar pustaka. Lembar kegiatan (LK) siswa dapat diisi dengan bimbingan guru serta siswa dapat memahami materi larutan elektrolit dan nonelektrolit. Hal ini sesuai dengan hasil penelitian Mahmoud (2014) melaporkan bahwa pembelajaran discovery learning membantu siswa belajar untuk diri mereka sendiri dan menerapkan apa yang diketahuinya dalam situasi yang baru, yang pada akhirnya akan menyebabkan tercapainya pembelajaran yang efektif. Hasil penelitian Balim (2009) malaporkan bahwa pembelajaran menggunakan model discovery learning meningkatkan hasil belajar siswa yang menandakan bahwa penggunaan model discovery learning efektif untuk meningkatkan hasil belajar siswa. Hal senada dikemukakan oleh Uside (2013) dengan hasil penelitian bahwa pembelajaran menggunakan model discovery learning meningkatkan hasil belajar kognitif siswa.

Kendala yang dihadapi selama penelitian adalah masih kurangnya motivasi dan keaktifan siswa selama proses pembelajaran. Hal ini diatasi dengan mengelompokkan siswa yang aktif dengan siswa yang kurang aktif sehingga siswa yang kurang aktif akan termotivasi untuk mengikuti proses pembelajaran. Selama proses pembelajaran waktu juga menjadi kendala karena pada kelas eksperimen siswa mengisi modul dengan membutuhkan waktu yang cukup lama. Hal ini menunjukkan bahwa model pembelajaran discovery learning membutuhkan waktu yang lama sehingga menyita waktu yang cukup banyak (Hosnan.2011:288).

Berdasarkan uraian di atas, dapat disimpulkan bahwa hasil belajar kognitif siswa yang menggunakan modul larutan elektrolit dan nonelektrolit berbasis discovery learning lebih tinggi dibanding siswa yang tidak menggunakan modul larutan elektrolit dan nonelektrolit berbasis discovery learning. Hal ini berarti penggunaan modul larutan elektrolit dan nonelektrolit berbasis discovery learning efektif terhadap hasil belajar. Penggunaan modul larutan elektrolit dan nonelektrolit berbasis discovery learning meningkatkan keterampilan berpikir kritis siswa selama proses pembelajaran yang terlihat pada jawaban lembar kegiatan dan lembar kerja siswa.

\section{KESIMPULAN}

Berdasarkan analisis data yang diperoleh dari hasil penelitian, bahwa hasil belajar kognitif kelas eksperimen yang menggunakan modul larutan elektrolit dan nonelektrolit berbasis discovery learning lebih tinggi dibanding kelas kontrol yang tidak menggunakan modul larutan elektrolit dan nonelektrolit berbasis discovery learning. Hal ini berarti penggunaan modul larutan elektrolit dan nonelektrolit berbasis discovery learning efektif terhadap hasil belajar. Penggunaan modul larutan elektrolit dan nonelektrolit berbasis discovery learning meningkatkan keterampilan berpikir kritis siswa yang terlihat 
pada nilai lembar kegiatan dan lembar kerja siswa yang tersedia pada modul.

\section{DAFTAR PUSTAKA}

[1] Balım, A., G. (2009). The Effects of Discovery Learning on Students' Success and Inquiry Learning Skills. Egitim Arastirmalari-Eurasian Journal of Educational Research, 35, 1-20.

[2] Depdiknas. (2003). Panduan Pengembangan Bahan Ajar. Jakarta: Depdiknas.

[3] Ellizar dan Djusmaini. (2012). Analisis Motivasi dan Berpikir Kritis Siswa Kelas XI IPA SMAN Kota Padang. Padang : UNP.

[4] Fitri A.P, Hairida, Rahmat R. (2014). Pengaruh Penggunaan Model Discovery Learning Dengan Pendekatan Saintifik Terhadap Keterampilan Berpikir Kritis Siswa Sma. Artikel Penelitian.

[5] Galuh A.I, Agung N.C. S.2 dan J.S Sukardjo. (2015). Penerapan Model Pembelajaran Discovery Learning Untuk Meningkatkan Aktivitas Dan Prestasi Belajar Pokok Bahasan Larutan Penyangga Pada Siswa Kelas XI IPA Semester II SMA Negeri 1 Ngemplak Tahun Pelajaran 2013/2014. Jurnal Pendidikan Kimia (JPK). Vol. 4 No. 2 Tahun 2015 Program Studi Pendidikan Kimia Universitas Sebelas Maret.

[6] Hosnan.(2014). Pendekatan Saintifik dan Kontektual Dalam Pembelajaran Abad 21. Jakarta: PT.Ghalia Indonesia.

[7] Kinasih, M.E, Tri J, Berti Y. 2015. Pengaruh Model Dicovery Learning terhadap Keterampilan Berpikir Kritis Siswa. Jurnal Bioterdidik Vol. 3 No. 10 Tahun 2015 Program Studi Pendidikan Biologi FKIP Universitas Lampung.

[8] Mahmoud, Abdelrahman. (2014). The Effect of Using Discovery Learning Strategy in Teaching Grammatical Rules to first year General Secondary Student on Developing Their Achievement and Metacognitive Skills. International Journal of Innovation and Scientific Research, vol. $5,146-153$.

[9] Nasution. S. (2011). Berbagai Pendekatan dalam Proses Belajar Mengajar. Jakarta: Bumi Aksara.

[10] Novayani, S, Asma, N, Ratna, A.M. 2015. Pengaruh model discovery learning terhadap keterampilan berpikir kritis siswa SMP pada pencemaran lingkungan. Jurnal Ilmiah Pendidikan Kimia “Hydrogen”, Vol. 3. No. 1.

[11] Prayesa, Esi.(2017). Pengembangan Modul Larutan Elektrolit Dan Non Elektrolit Berbasis Discovery Learning Untuk Kelas X Sma/Ma. Skripsi. Universitas Negeri Padang.

[12] Sudjana.(2005). Metode Statistik. Bandung: Tarsito

[13] Sugiyono.(2013). Metode Penelitian Kombinasi. Bandung : Alfabeta.

[14] Sunaryo, Yoni.(2014). Model Pembelajaran Berbasis Masalah Untuk Meningkatkan Kemampuan Berpikir Kritis Dan Kreatif Matematik Siswa SMA Di Kota Tasikmalaya. Jurnal Pendidikan dan Keguruan .Vol. 1 No. 2,2014, artikel 5.

[15] Syamsul, Rijal.(2013). Pengembangan Modul Pembelajaran Kimia SMA Berorientasi Karakter. Jurnal Nalar Pendidikan. Volume 1.Nomor 1. ISSN: 2339-0749.

[16] Udo, M.E. (2010). Effect Of Guided Discovery,Student-CentredDemonstration And The Expository Instructional Strategies On Students' Performance In Chemistry. Journal Multi-Disiplin Internasional, Ethiopia; Vol.4 (4), Serial No. 17, October, 2010. Hal: 389-398.

[17] Uside, O.N. (2013). Effect Of Discovery Method On Secondary School Student's Achievement In Physics In Kenya. Asian Journal Of Social Sciences \& Humanities. Vol. 2, No. 3 Hal. 357.

[18] Yerimadesi, Putra, A, Ririanti. (2017). Efektivitas Penggunaan Modul Larutan Penyangga Berbasis Discovery Learning Terhadap Hasil Belajar Siswa Kelas XI MIA Sman 7 Padang. Jurnal Eksakta Pendidikan. Volume 1, No. 1.

[19] Yerimadesi, Bayharti, Fitri, H, Wiwit F.L.2016. Pengembangan Modul Kesetimbangan Kimia Berbasis Pendekatan Saintifik Untuk Kelas XI SMA/MA. Journal Of Sainstek. 8(1):85-97.

[20] Zainul, Rahadian. .2016. Disain, Metode Dan Penggunaan Software Pembelajaran Kimia Berbasis It Untuk Aktivitas Kelas dan Laboratorium Berbasis Inkuiri Terbimbing. Seminar Nasional Kimia FMIPA UNP. https://doi.org/10.31227/osf.io/psf5t 
[21] Zainul, R., \& Jannah, A. R. 2017. Pengembangan Media Pembelajaran Asam Basa Menggunakan Aplikasi Android Berbasis Chemistry Triangle Kelas XI SMA/MA. Skripsi. FMIPA UNP. https://doi.org/10.31227/osf.io/muh8y 